\title{
Contingent Crop Planning for Proactive Monsoon Management under Rainfed Regions
}

\author{
J.K. Balyan*, Anil Kumar Kothari and Ramavtar \\ College of Agriculture, Bhilwara, Maharana Pratap University of Agriculture and \\ Technology, Udaipur, India \\ *Corresponding author
}

\section{A B S T R A C T}

For adopting a particular cropping plan, the time of onset of monsoon is the most important single parameter but it has not been considered in most of the studies conducted for crop planning under rainfed regions. Rainfall data of Bhilwara district in Rajasthan state for a period of 57 years were analysed from two approaches viz.; 'Meteorological' approach and 'Onset of monsoon' approach. The 'Meteorological' approach is a

\section{Keywords}

Rainfed,

Evapotranspiration,

Unimodal, Dryland,

Contingent

Article Info

Accepted:

07 October 2018

Available Online:

10 November 2018 conventional approach wherein the information for crop growth period is assumed based on normal week of onset of monsoon and also provides a single set of information which leads to a single set of cropping plan irrespective of time of onset of monsoon. On the contrary in the 'Onset of monsoon' approach, the rainfall data are arranged by considering onset of monsoon as datum and also grouped for different weeks of onset of monsoon. The results reveal considerable difference in rainfall characteristics with respect to length of growing period, water surplus/ deficit and probability of intervening dry spells due to these approaches. The 'Onset of monsoon' approach is more rational as it precisely describes the actual crop environment and provides information for varying onsets of monsoon as compared to 'Meteorological' approach. The results of water balance study reveals an increase of water deficit due to early and delay in onset (31st SMW) as compared to normal onset of monsoon (27th SMW), whereas an decrease of 50.2 per cent in water surplus and a decrease of 55.8 per cent in water surplus was recorded due to late and early onset of monsoon as compared to normal onset of monsoon. The correlation studies also reveal that onset of monsoon is inversely correlated $(-0.91)$ with duration of rainy season while positively correlated (0.83) with water deficit. Thus, the 'onset of monsoon' approach should be considered for crop planning under rainfed regions to harness more profit per unit of rainfall.

\section{Introduction}

In general for crop planning, rainfall analysis and water balance studies have been carried out to determine seasonal and weekly rainfall, onset and withdrawal of monsoon, intervening critical dry spells, water surplus/ deficit for different standard meteorological weeks by several researchers (Singh and Hazra, 1999; Panigrahi and Panda, 2002; Satpute, 2004; Deora, 2005; Jat et al., 2005; and Singh, 2005). The weekly information for crop growing period has been determined by considering the normal onset of monsoon 
week as datum. The information so generated is misleading and not much useful for crop planning, because it does not represent the actual crop growing season. The onset of monsoon is variable in each year as compared to normal week of onset of monsoon and leads to different dates of sowing of crops in each year. Further, analyses of rainfall and water balance results in a single set of decision (at a particular probability level, say $70 \%$ ) leading to only one set of recommendation for crop planning. Thus, this approach has in general two limitations viz.; it does not consider the variability of onset of monsoon in each year and it leaves the farmer confined to a single set of decision without considering the variability of onsets of monsoon in each year. This conventional approach has been termed as "Meteorological" approach.

The onset of monsoon is the only rainwater balance parameter known prior to major decision making for crop planning and it has also been reported that the onset of monsoon week has significant inverse correlation with monthly and monsoon season rainfall $(\mathrm{CH}$. Srinivasa Rao et al., 2016 and Agnihotri and Murti, 2001). Further, it has been suggested to identify and quantify seasonal rainfall variability and its related risks with variability of onset of monsoon for managing the climatic risks in crop production (Stewart, 1991).

Therefore, it is rational to accept the onset of monsoon as origin for demarcating rest of weeks as week from onset of monsoon each year and generate information for actual crop growing season. Further, deviation in time of onset of monsoon leads to different climatic environment for crop which demands for characterization of rainfall and water balance for each week of onset of monsoon. The approach of 'onset of monsoon' leads to multiple set of decisions and also it reduces the range of variability of seasonal rainfall characteristics. Thus, it suggests dynamic recommendations for each set of onset of monsoon instead of static recommendation based on normal onset of monsoon for crop planning. This approach is termed as 'Onset of monsoon' approach.

Therefore, a study on rainfall analysis was conducted for evaluating the 'Meteorological' and 'Onset of monsoon' approaches in Bhilwara district of Rajasthan state to suggest more rational method for generating information for crop growing season.

\section{Materials and Methods}

The study was conducted in Bhilwara district which lies at $25^{\circ} \mathrm{N}$ latitude, $75^{\circ}$ longitude and altitude of $463.2 \mathrm{~m}$ above mean sea level. Daily rainfall data for a period of 57 years (1960-2016) were collected from the Office of the District Collector, Bhilwara in Rajasthan state. The weekly meteorological data recorded at Dryland Farming Research Station, Bhilwara (Research Station) for a period of 32 years (1985-2016) were used for determination of weekly reference evapotranspiration. The region under study receives an annual rainfall of $608.4 \mathrm{~mm}$ and ranges from $277.2 \mathrm{~mm}$ to $1091.7 \mathrm{~mm}$ with a coefficient of variation of 31.24 per cent. Almost 90 per cent of annual rainfall is received during rainy season (June to September). The soils of the region are sandy loam to clay loam in texture having shallow to medium depth. The principle crops in the region are maize, groundnut, black gram, green gram, sesame and sorghum fodder during kharif season.

\section{Onset and withdrawal of monsoon}

It was computed by using a modified Morris and Zandstra (1979) method which was validated from the observed onset of monsoon at the Research Station and is described below. 
The onset of monsoon in a standard meteorological week (SMW) is considered if the forward accumulation of weekly rainfall is reached to a predetermined quantity of 100 $\mathrm{mm}, 75 \mathrm{~mm}$ and $30 \mathrm{~mm}$ up to 25,26 and onward 26 SMW with a condition that any week having $0.0 \mathrm{~mm}$ rainfall than restart accumulation of rainfall from that SMW.

The withdrawal of monsoon in a SMW is considered if the backward accumulation of weekly rainfall is $10 \mathrm{~mm}$ in that SMW from $47^{\text {th }}$ week considering mono cropped area having maximum crop duration of 18 weeks (Groundnut) and normal week of onset of monsoon.

\section{Dry spell analysis}

Rainfall of $20 \mathrm{~mm}$ per week is adequate for all the growth stages of the crops grown in the region. Thus, if in a given week the rainfall received is less than $20 \mathrm{~mm}$ then week can be designated as a dry week else wet week (Pandarinath, 1991). The probability of dry week and two consecutive dry weeks were computed by Markov chain process as suggested by Robertson (1976).

\section{Water balance}

Reference evapotranspiration was calculated by widely accepted Penman-Monteith FAO-56 method as suggested by Allen et al., (1998). Soil resources information for the tehsils was obtained from National Bureau of Soil Survey and Land Use Planning, Regional Centre, Udaipur (Jain et al., 2000). Soils of the region are sandy loam to clay loam in texture having available water holding capacity of from 90 to $200 \mathrm{~mm}$.

The weekly soil water balance was computed following the book keeping procedure suggested by Thornthwaite and Mather (1955).

\section{Moisture adequacy index}

It was computed as suggested Krishnan (1979) from the following criteria for weekly soil moisture adequacy index:

$\mathrm{MAI}=\mathrm{AE} / \mathrm{ETo} \times 100$.

Classification of MAI on Weekly basis are decided as follows

MAI $>=75 \%$ (Excellent),

MAI $=50$ to $74 \%$ (Good)

$\mathrm{MAI}=49$ to $24 \%$ (Poor)

MAI $<24 \%$ (Very Poor)

Moisture status, If MAI $=0$ to 49 , during active growth stages of the crop, it is considered as drought. Where, AE and ETo are actual and reference evapotranspiration for the period.

\section{Outcomes}

The onset of monsoon was determined from the modified Morris and Zandstra method for 57 years (1960-2016) of rainfall data. Rainfall analysis for dry spell and water balance was carried out by 'meteorological' approach and first step of 'Onset of monsoon' approach (considering onset of monsoon as datum).

Further, rainfall characteristics, water surplus / deficit and moisture adequacy index (MAI) were also used to determine for different weeks of onset of monsoon from 'Meteorological' and 'Onset of monsoon' approach. The results obtained thus are compared for obtaining the more appropriate approach for crop planning.

\section{Characteristics of rainy season}

The onset and withdrawal of monsoon is determined from the modified Morris and Zandstra method. 
Fig.1 Moisture adequacy index for different weeks of onset of monsoon (1960-2016)

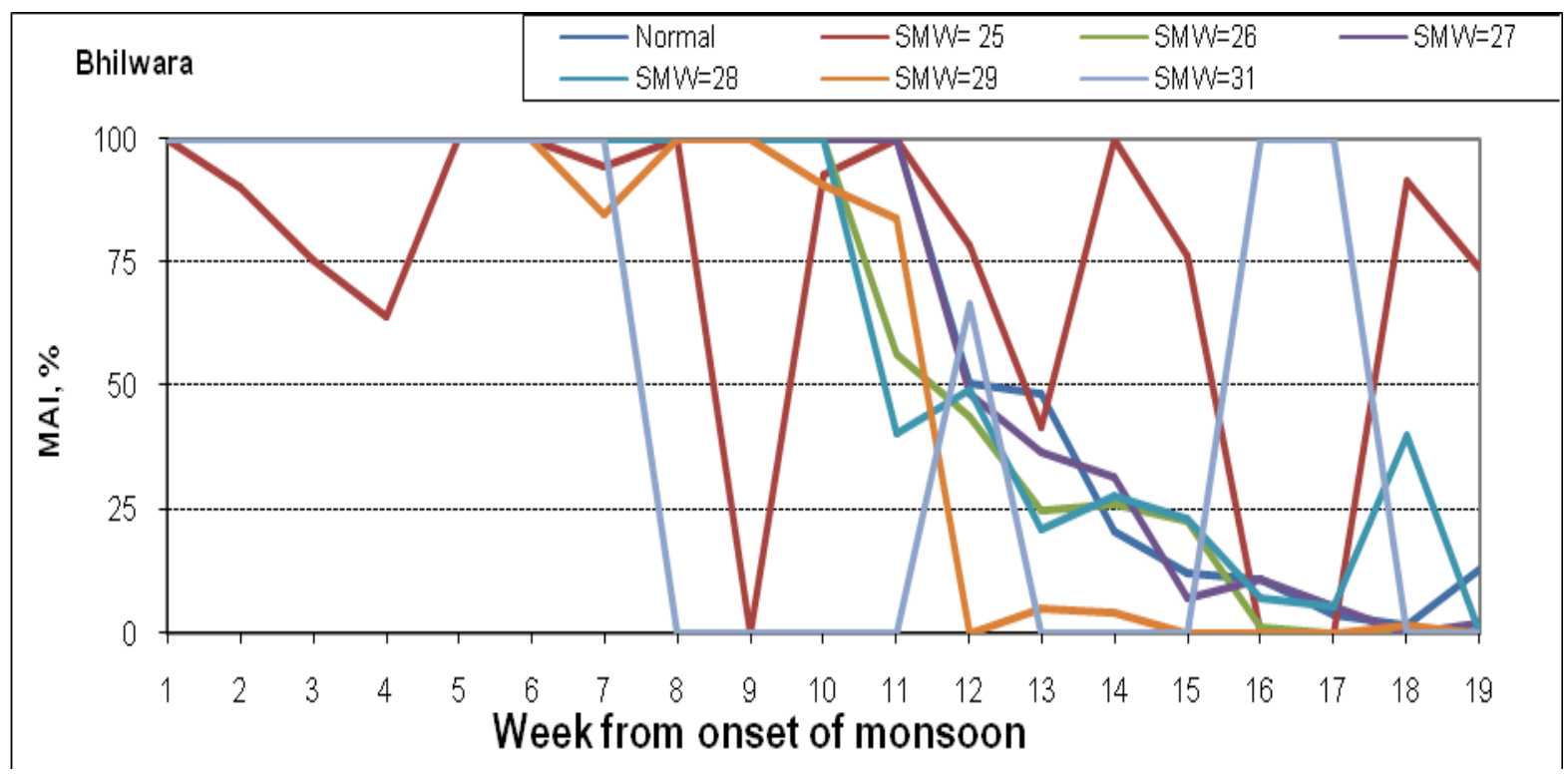

Fig.2 Effect of onset of monsoon on normal water balance parameters (1960-2016)

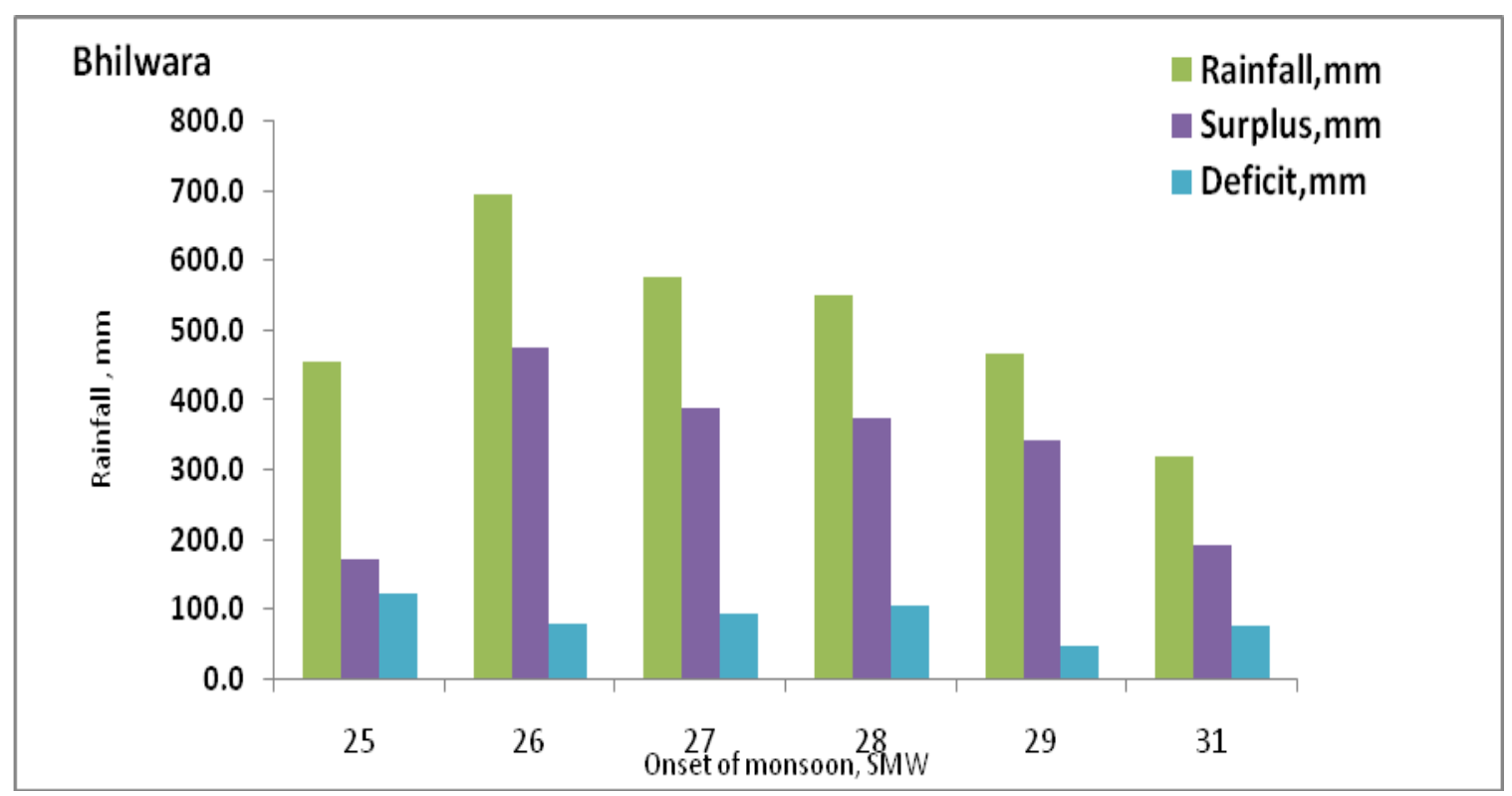

Table.1 Characteristics of rainy season at Bhilwara

\begin{tabular}{|c|c|c|c|c|c|c|c|c|}
\hline \multicolumn{3}{|c|}{$\begin{array}{c}\text { Onset of monsoon, } \\
\text { SMW }\end{array}$} & \multicolumn{3}{c|}{ Withdrawal of monsoon, } & \multicolumn{3}{c|}{$\begin{array}{c}\text { Length of rainy season, } \\
\text { weeks }\end{array}$} \\
\hline Early & Late & Mean & Early & Late & Mean & Maxi. & Mini. & Mean \\
\hline 25 & 31 & 27.5 & 33 & 47 & 38.4 & 19 & 4 & 10.8 \\
\hline
\end{tabular}

Figures in parenthesis indicate number of the event 
Int.J.Curr.Microbiol.App.Sci (2018) 7(11): 845-854

Table.2 Initial and conditional probability of dry week from different approaches

\begin{tabular}{|c|c|c|c|c|c|c|c|}
\hline & Meteorological approach & \multicolumn{4}{|c|}{ Onset of monsoon approach } \\
\hline SMW & $\mathbf{P}(\mathbf{D})$ & $\mathbf{P}(\mathbf{D} / \mathbf{W})$ & $\mathbf{P}(\mathbf{D} / \mathbf{D})$ & Week & $\mathbf{P}(\mathbf{D})$ & $\mathbf{P}(\mathbf{D} / \mathbf{W})$ & $\mathbf{P}(\mathbf{D} / \mathbf{D})$ \\
\hline 27 & 40 & 26 & 74 & 1 & 0 & 0 & 0 \\
\hline 28 & 39 & 59 & 41 & 2 & 28 & 100 & 0 \\
\hline 29 & 30 & 59 & 41 & 3 & 35 & 65 & 35 \\
\hline 30 & 37 & 57 & 43 & 4 & 40 & 61 & 39 \\
\hline 31 & 37 & 62 & 38 & 5 & 32 & 56 & 44 \\
\hline 32 & 28 & 63 & 38 & 6 & 44 & 60 & 40 \\
\hline 33 & 35 & 55 & 45 & 7 & 42 & 25 & 71 \\
\hline 34 & 42 & 42 & 58 & 8 & 46 & 46 & 54 \\
\hline 35 & 54 & 39 & 58 & 9 & 47 & 37 & 63 \\
\hline 36 & 56 & 41 & 59 & 10 & 58 & 30 & 70 \\
\hline 37 & 65 & 27 & 73 & 11 & 74 & 33 & 67 \\
\hline 38 & 86 & 29 & 69 & 12 & 84 & 17 & 81 \\
\hline 39 & 86 & 10 & 90 & 13 & 89 & 14 & 86 \\
\hline 40 & 91 & 13 & 87 & 14 & 88 & 8 & 92 \\
\hline 41 & 93 & 9 & 91 & 15 & 91 & 12 & 88 \\
\hline 42 & 95 & 7 & 93 & 16 & 93 & 6 & 94 \\
\hline 43 & 96 & 4 & 96 & 17 & 95 & 4 & 96 \\
\hline 44 & 100 & 4 & 96 & 18 & 96 & 4 & 96 \\
\hline 45 & 98 & 0 & 100 & 19 & 98 & 2 & 98 \\
\hline
\end{tabular}

P (D): Probability of dry week,

Table.3 Normal water balance from different approaches

\begin{tabular}{|c|c|c|c|c|c|c|c|c|c|c|c|c|c|}
\hline & \multicolumn{6}{|c|}{ Meteorological approach } & \multicolumn{7}{|c|}{ Onset of monsoon approach } \\
\hline SMW & PPT & ET0 & AET & SPL & DEF & MAI & Week & PPT & PET & AET & SPL & DEF & MAI \\
\hline 27 & 43.41 & 35.10 & 35.10 & 8.31 & 0.00 & 100 & 1 & 82.56 & 35.07 & 35.07 & 47.50 & 0.00 & 100 \\
\hline 28 & 43.75 & 27.30 & 27.30 & 16.45 & 0.00 & 100 & 2 & 58.73 & 28.61 & 28.61 & 30.12 & 0.00 & 100 \\
\hline 29 & 52.92 & 28.60 & 28.60 & 24.32 & 0.00 & 100 & 3 & 46.89 & 24.89 & 24.89 & 22.00 & 0.00 & 100 \\
\hline 30 & 60.08 & 24.44 & 24.44 & 35.64 & 0.00 & 100 & 4 & 53.58 & 22.36 & 22.36 & 31.22 & 0.00 & 100 \\
\hline 31 & 58.71 & 20.15 & 20.15 & 38.56 & 0.00 & 100 & 5 & 61.94 & 19.27 & 19.27 & 42.66 & 0.00 & 100 \\
\hline 32 & 70.12 & 17.55 & 17.55 & 52.57 & 0.00 & 100 & 6 & 47.29 & 18.04 & 18.04 & 29.25 & 0.00 & 100 \\
\hline 33 & 60.87 & 17.42 & 17.42 & 43.45 & 0.00 & 100 & 7 & 55.66 & 18.29 & 18.29 & 37.37 & 0.00 & 100 \\
\hline 34 & 54.37 & 18.33 & 18.33 & 36.04 & 0.00 & 100 & 8 & 44.78 & 18.67 & 18.67 & 26.11 & 0.00 & 100 \\
\hline 35 & 31.16 & 19.24 & 19.24 & 11.92 & 0.00 & 100 & 9 & 42.12 & 18.16 & 18.16 & 23.96 & 0.00 & 100 \\
\hline 36 & 36.32 & 18.46 & 18.46 & 17.86 & 0.00 & 100 & 10 & 29.71 & 18.50 & 18.50 & 11.21 & 0.00 & 100 \\
\hline 37 & 17.89 & 16.77 & 16.77 & 1.12 & 0.00 & 76 & 11 & 14.42 & 18.92 & 14.42 & 0.00 & 4.50 & 76 \\
\hline 38 & 9.22 & 18.20 & 9.22 & 0.00 & 8.98 & 51 & 12 & 7.73 & 20.47 & 7.73 & 0.00 & 12.74 & 38 \\
\hline 39 & 9.49 & 19.63 & 9.49 & 0.00 & 10.14 & 48 & 13 & 4.40 & 22.05 & 4.40 & 0.00 & 17.65 & 20 \\
\hline 40 & 4.90 & 23.66 & 4.90 & 0.00 & 18.76 & 21 & 14 & 5.80 & 23.13 & 5.80 & 0.00 & 17.33 & 25 \\
\hline 41 & 2.69 & 22.49 & 2.69 & 0.00 & 19.80 & 12 & 15 & 3.55 & 23.50 & 3.55 & 0.00 & 19.95 & 15 \\
\hline 42 & 2.78 & 25.61 & 2.78 & 0.00 & 22.83 & 11 & 16 & 2.92 & 23.29 & 2.92 & 0.00 & 20.37 & 13 \\
\hline 43 & 0.96 & 26.00 & 0.96 & 0.00 & 25.04 & 4 & 17 & 1.44 & 21.79 & 1.44 & 0.00 & 20.35 & 7 \\
\hline 44 & 0.32 & 20.15 & 0.32 & 0.00 & 19.83 & 2 & 18 & 0.36 & 19.09 & 0.36 & 0.00 & 18.74 & 2 \\
\hline 45 & 2.10 & 16.38 & 2.10 & 0.00 & 14.28 & 13 & 19 & 0.11 & 15.26 & 0.11 & 0.00 & 15.15 & 1 \\
\hline Total & 562.1 & 415.5 & 275.8 & 286.2 & 139.7 & & Total & 564.0 & 409.4 & 262.6 & 301.4 & 146.8 & \\
\hline
\end{tabular}


Table.4 Effect of onset of monsoon on normal water balance parameters

\begin{tabular}{|c|c|c|c|c|}
\hline Onset of monsoon SMW & $\begin{array}{c}\text { Rainfall } \\
\text { amount, } \mathbf{~ m m}\end{array}$ & $\begin{array}{c}\text { Duration of rainy } \\
\text { season, week }\end{array}$ & $\begin{array}{c}\text { Water } \\
\text { surplus, mm }\end{array}$ & $\begin{array}{c}\text { Water deficit, } \\
\mathbf{m m}\end{array}$ \\
\hline 25 & 457.5 & 12.0 & 172.6 & 124.7 \\
\hline 26 & 694.8 & 10.8 & 475.5 & 79.5 \\
\hline 27 & 578.6 & 11.6 & 390.7 & 95.8 \\
\hline 28 & 552.8 & 11.8 & 374.3 & 107.2 \\
\hline 29 & 469.1 & 7.1 & 344.5 & 50.2 \\
\hline 31 & 322.0 & 5.0 & 194.6 & 78.4 \\
\hline Correlation Coefficient & -0.57 & -0.91 & -0.37 & 0.83 \\
\hline
\end{tabular}

$*$ Significant at $5 \%$ probability level, $\mathrm{r}=0$.

Table.5 Contingent crop plan for midseason corrections around the year with different crop and cropping systems and cultural practices

\begin{tabular}{|l|l|l|}
\hline Month & $\begin{array}{l}\text { Crop/ Intercropping } \\
\text { (Varieties) }\end{array}$ & $\begin{array}{l}\text { Cultural operations including mid- } \\
\text { season corrections }\end{array}$ \\
\hline April & - & $\begin{array}{l}\text { Deep summer ploughing, peripheral } \\
\text { bunding, Chiseling etc. }\end{array}$ \\
\hline May & $\begin{array}{l}\text { Arrangement of input viz., seed, } \\
\text { fertilizer, insecticide and pesticides }\end{array}$ \\
\hline II Fortnight & $\begin{array}{l}\text { Maize- PM-3, PM-5, PEHM-2, HQPM- } \\
\text { Field preparation for using pre } \\
\text { monsoon shower } \\
\text { Sorghum - CSH-15, CSV-17 } \\
\text { Groundnut- TAG-24, TG37A, GG-7 \& } \\
\text { Seed bed preparation and sowing of } \\
\text { crops }\end{array}$ \\
& $\begin{array}{l}\text { Intercropping systems: Maize + } \\
\text { blackgram (2:2), Groundnut +Sesame } \\
\text { (6:2) }\end{array}$ & \\
\hline $\begin{array}{l}\text { July- I } \\
\text { Fortnight }\end{array}$ & $\begin{array}{l}\text { Sorghum - CSH-17 \& CSV-15, Sesame } \\
\text { - RT- 125 \& RT-351, Groundnut- } \\
\text { TG37A, GG-7 \& Pratap Mungfali-2 } \\
\text { Blackgram- PU-31, Pratap urd-1, } \\
\text { Horsegram- AK-21 \& AK-42 } \\
\text { Greengram -IPM-02-03, RMG-492, } \\
\text { SML-668, } \\
\text { Bajra and cowpea } \\
\text { Castor- GCH-5, GCH-7\& RCH-1 } \\
\text { Clusterbean-RGC-936, RGC-1033, } \\
\text { RGC-1002 \& RGC-1055 } \\
\text { Intercropping systems: Maize + black } \\
\text { gram (2:2),Castor +Greengram (1:2), } \\
\text { Groundnut +Sesame (6:2) }\end{array}$ \\
\hline
\end{tabular}




\begin{tabular}{|c|c|c|}
\hline $\begin{array}{l}\text { July- II } \\
\text { Fortnight }\end{array}$ & $\begin{array}{l}\text { Green gram - RMG-492, SML-668, } \\
\text { IPM-02-03, RMG-492 } \\
\text { Blackgram -PU-31 \& Pratap Urd-1 } \\
\text { Sesame - RT- 125 \& RT-351, } \\
\text { Horsegram- AK-42 \& AK-53 } \\
\text { Sorghum - CSV-15 (Dual purpose) \& } \\
\text { Pratap Jowar -1430 }\end{array}$ & $\begin{array}{l}\text { Dry sowing if monsoon delayed } \\
\text { Seed bed preparation \& Sowing } \\
\text { Seed treatment } \\
\text { Plant protection measures }\end{array}$ \\
\hline $\begin{array}{l}\text { August- I } \\
\text { Fortnight }\end{array}$ & $\begin{array}{l}\text { Sorghum (fodder) under delayed onset } \\
\text { of monsoon }\end{array}$ & $\begin{array}{l}\text { Thinning of alternate plants if } \\
\text { prolonged drought prevails, removal of } \\
\text { weeds, Earthling in groundnut and } \\
\text { ridging in maize, foliar application of } \\
\text { soluble N,P,K }(1 \%) \& \text { zinc sulphate } \\
(0.5 \%) \text { in cereals. Lifesaving irrigation } \\
\text { in case of mid-season drought. } \\
\text { Kharif fallow or failed kharif situation }\end{array}$ \\
\hline $\begin{array}{l}\text { September- I } \\
\text { Fortnight } \\
\text { II Fortnight }\end{array}$ & & $\begin{array}{l}\text { Thinning of alternate rows if acute } \\
\text { drought prevails, Recycling of } \\
\text { harvested rainwater Interculture, } \\
\text { Picking of pods in greengram and } \\
\text { harvesting of sorghum fodder }\end{array}$ \\
\hline \multirow[t]{2}{*}{ II Fortnight } & & $\begin{array}{l}\text { Harvesting of maize, blackgram, } \\
\text { greengram and groundnut. Tillage and } \\
\text { field preparation for early rabi seeding } \\
\text { if rain received or moisture conserve. } \\
\text { Shallow tillage for seed bed } \\
\text { preparation, sowing, basal application } \\
\text { of fertilizer, seed treatment }\end{array}$ \\
\hline & $\begin{array}{l}\text { Taramira- RTM } 314 \text { \& RTM 2002, } \\
\text { Mustard- Griraj, Laxmi }\end{array}$ & $\begin{array}{l}\text { Ensure adequate plant protection } \\
\text { measures for establishment of rabi } \\
\text { crops } \\
\text { Shallow tillage for seed bed } \\
\text { preparation, sowing, basal application } \\
\text { of fertilizer, seed treatment }\end{array}$ \\
\hline $\begin{array}{l}\text { October- I } \\
\text { Fortnight }\end{array}$ & $\begin{array}{l}\text { Mustard : Griraj, Laxmi, Bio } 902 \\
\text { Gram :PratapChana-1, Dohad yellow } \\
\text { Gram (PratapChana-1) + Mustard }\end{array}$ & $\begin{array}{l}\text { Harvesting of maize and groundnut } \\
\text { Threshing and winnowing of products }\end{array}$ \\
\hline November & Wheat- Raj-4037 & $\begin{array}{l}\text { Under tank bed conditions release of } \\
\text { stored water after Sowing }\end{array}$ \\
\hline December & & $\begin{array}{l}\text { Soil mulching, interculture } \\
\text { Wheel hoe may be used }\end{array}$ \\
\hline January & & Plant protection measures \\
\hline February & & $\begin{array}{l}\text { Harvesting of toria, taramira and } \\
\text { mustard }\end{array}$ \\
\hline March & & Harvesting of wheat \\
\hline
\end{tabular}


Considerable variation in onset and withdrawal of the monsoon was observed from year to year. Therefore, the mean, earliest and latest SMW during which the onset and withdrawal of monsoon have commenced are given in Table 1. The data reveal that the normal week of onset and withdrawal of monsoon were observed in 27th and 38th SMW, respectively. While the earliest onset and withdrawal of monsoon was observed in 25th and 33rd SMW, respectively. The onset of monsoon was observed for 1, 11, 17, 17, 9 and 2 year out of 57 years in 25th, 26th, 27th, 28th, 29th and 31st SMW, respectively. The length of rainy season varied from 4 to 19 weeks with a mean of 10.8 weeks.

\section{Probability of dry week}

The initial and conditional probabilities of dry weeks have been determined from 'Meteorological' and 'Onset of monsoon' approaches. The results presented (19602016) in Table 2 reveal a significant difference in probability levels during initial period of six weeks and thereafter difference is narrowed down. For example, the probability of dry week in 27th SMW (normal week onset of monsoon) is 40 per cent due to 'Meteorological' approach against nil probability due to 'Onset of monsoon' approach. The results obtained are quite different and controversial. The amount of rainfall accumulation for considering the onset of monsoon was more than $30 \mathrm{~mm}$ per week, which implies that the results obtained from 'Onset of monsoon' are justified and it also reveals the lacuna of not considering the shift in origin of onset of monsoon in the conventional 'Meteorological' approach. The controversy in the results is due to shift in origin of onset of monsoon only. Similarly, the data presented in Table 2 indicate difference in probability levels for conditional probabilities of dry weeks in different weeks for crop growth period. However, results obtained from 'onset of monsoon' have been considered for crop planning.

\section{Normal water balance}

Normal water balance has been determined from aforesaid approaches and results presented (1960-2016) in Table 3 reveal that surplus water is available from 1st week for 10 consecutive weeks due to 'Onset of monsoon' approach whereas from 1st week (27th SMW) for 11 consecutive weeks due to 'Meteorological' approach. Similarly, an increase of 5.29 per cent in total surplus water available is recorded due to former approach as compared to latter approach $(286.2 \mathrm{~mm})$. While no significant difference was observed for available water deficit and moisture adequacy index as the shift in origin of onset of monsoon affects the water balance parameters during initial period which is having water surplus only. Thus, the results reveal a significant difference in probabilities of dry weeks and water surplus due to shift in datum at actual week of onset of monsoon. Therefore, rainfall characteristics and water deficit /surplus for different weeks of onset of monsoon were determined and correlated with week of onset of monsoon.

\section{Onset of monsoon and water balance parameters}

The onset of monsoon is the only known monsoon parameter before putting the seed in the soil and relating it with rainfall characteristics or water balance will be of great importance for agriculturist and farmers. Therefore, mean rainfall parameters like duration of rainy season, rainfall amount, number of rainy days and water surplus / deficit were determined for different weeks of onset of monsoon and presented in Table 4. The correlation between rainfall characteristics and onset of monsoon is also 
determined. The results reveal a negative correlation coefficient ( $r$ ) for all the rainfall characteristics except water deficit. Thus, the delay in onset of monsoon reduces the duration of rainy season, rainfall amount, number of rainy days and water surplus while it increases the water deficit. The same phenomenon has been observed by Stewart (1990) in Kenya. Similarly, Agnihotri and Murti (2001) have also observed that delay in onset of monsoon reduces the monsoon season rainfall. The duration of rainy season is inversely correlated $(r=-0.91)$ with onset of monsoon while water deficit has strongly positive correlation coefficient $(r=0.83)$ with onset of monsoon. However, water surplus is poorly correlated $(\mathrm{r}=-0.37)$ with onset of monsoon. The results presented in Table 4 also reveal an increase of water deficit due to early and delay in onset (31st SMW) as compared to normal onset of monsoon (27th SMW). Thus, the early and late onset of monsoon results in more water deficit as compared to normal onset of monsoon.

The results also reveals an decrease of 50.2 per cent in water surplus and a decrease of 55.8 per cent in water surplus due to late (31st SMW) and early onset (25th SMW) as compared to normal onset of monsoon in 27th SMW (390.7 mm). The weekly moisture adequacy index was also determined for different weeks of onset of monsoon and presented in Figure 1, which reveal that a significant decrease in length of crop growing period as the week of onset of monsoon was delayed. The Figure 1 also reveals that length of crop growing season reduces drastically if the onset of monsoon is excessively delayed (31st SMW). On the contrary excessively early onset of monsoon (25th SMW) results in maximum length of growing season except initial dry spells in general, while a decrease in length of growing season was observed due to delay in onset of monsoon (from 26th to 29th SMW) as depicted in figure.

\section{Crop planning based on onset of monsoon}

The above analysis suggests that while making selection of crops and their cultivars for dryland areas under semi-arid agro-eco region one should consider the timeliness of monsoon arrival. The early onset of monsoon suggests to take long duration crops like groundnut and maize (Hybrids) as it is expected to have prolonged rainy season, whereas normal onset of monsoon suggests for cultivation of maize (Composites), black gram and recommended intercropping systems viz.; Maize +black gram and groundnut + sesame, while the delayed onset of monsoon suggests for kharif pulses due to short duration crop and sesame because of poor correlation with onset of monsoon. Further, in case of extra ordinary delay in onset of monsoon (31st SMW) fodder crops like sorghum, bajra and cowpea are suggested instead of grain crops. Above recommendations should be taken as a guideline to increase or decrease the area allocation by the farmers for suggested crops based on land capability, minimization of the risk and family requirements (Fig. 2).

From the study, it can be concluded that the 'Onset of monsoon' approach was found superior and rational as compared to 'Meteorological' approach for analysis of rainfall data for crop planning. The former approach provides an opportunity to suggest dynamic crop planning in relation to different weeks of onset of monsoon and it reduces the variability of rainfall characteristics while the later approach suggests for static crop planning ignoring the importance of onset of monsoon and also provides an envelope having total variability of rainfall characteristics which have a limited use for crop planning. Thus, it is recommended that rainfall analysis for crop planning should be carried out from the rational approach of 'Onset of monsoon' to augment the crop yield 
per unit of rainfall under dryland conditions having unimodal rainfall pattern.

\section{References}

Agnihotri, Y. and Murti, Ram. 2001. Relationship between onset of monsoon with sowing weeks and monthly/ seasonal rainfall at Chandigarh. J. Indian Water Reso. Soc. 21(2): 60-64.

Allen, R.G., Pereira, I.S., Daes, D. and Smith, M. 1998. Crop evapotranspiration, Guideline for Computing Crop Water Requirements. FAO Irrig. Drain, Paper 56. Rome, Italy. Pp. 300.

Deora, B.S. 2005. Modeling of Drought under different Agro-climatic Zones of Gujarat and Maharashtra. Unpublished Ph.D. Thesis, Department of Soil and Water Engg. CTAE, MPUAT, Udaipur. pp.264

Jat, M.L., Singh, R.V., Balyan, J.K. and Jain, L.K. 2005. Rainfall analysis for crop planning in Udaipur region. Indian $\mathrm{J}$. Soil Cons. 33(3): 264-266.

Morris, R.A. and Zandstra, H.G., 1979. Land and climatic in relation to cropping patterns. In rainfed low land rice, selected papers from 1970. Int. Rice Res. Conf. IRRI., pp. 255-274.

Pandarinath, 1991. Markov Chain model probability of dry and wet weeks during monsoon period over Andhra Pradesh. Mausam, 42(4): 393-400.

Panigrahi, B. and Panda, S.N. 2002. Dry spell probability by Markov Chain model and its application to crop planning. Indian J. Soil Cons. 30(1):95-100
Robertson, G.W. 1976. Dry and wet spell UNDP/FAO, Tun Razak Agric. Res., Center, Sungh: Tekam, Malaysia, project field report, Agrometeorology. A-6. p. - 15.

Satpute, G.U. 2004. Characterization of Drought under different Agro-climatic Zones of Maharashtra. Unpublished Ph. D. Thesis Deptt. of Soil and Water Engg. CTAE, MPUAT, Udaipur. pp.199

Singh, J.B. and Hazra, C.R. 1999. Rainfall characteristics of Jhansi for crop planning under rainfed condition- A decadal change. Journal of Soil and Water Conservation, Vol. 43. pp 25-34.

Singh, P.K. 2005. Rainfall variability and crop planning in Sabour region of Bihar. Journal of Agrometeorology. 7(2): 284-290.

Srinivasa CH. R., Ravindra Chary, G., Rani, N. and Baviskar, V. S. 2016. Real time implementation of agricultural contingency plans to cope with weather aberrations in Indian agriculture. Masum, 6 7(1): 183-194.

Stewart, J. 1991. Principles and performance of response farming In: Climatic risks in crop productions-Models and management for semiarid tropics and subtropics, Edited by Russcell C. Muchow and Jennifer A. Bellamy, CAB International, United Kingdom (total p548): pp 361-382.

Thornthwaite, C.W. and Mather, J.R. 1955. The Water Balance Climate. Dreseat Inst. of Tech., New Jersey. USA (total p 104). Chapter 8(1).

\section{How to cite this article:}

Balyan, J.K., Anil Kumar Kothari and Ramavtar. 2018. Contingent Crop Planning for Proactive Monsoon Management under Rainfed Regions. Int.J.Curr.Microbiol.App.Sci. 7(11): 845-854. doi: https://doi.org/10.20546/ijcmas.2018.711.100 